\title{
写真技術を用いたX線写真のフィルタリング
}

\author{
大阪市立大学医学部附属病院中央放射線部
}

畑 II 政勝

（論文受付 昭和51年1月20日）

(Code No. 233)

\section{FILTERING OF RADIOGRAPHIC IMAGES WITH PHOTOGRAPHIC TECHNIQUES}

(Artide received: Jan. 20, 1976)

\author{
By Masakatu Hatagawa \\ Department of Radiology, Osaka City \\ University Hospital
}

\section{Summary}

Image processing by optical filtering technique is applied for enhancement of radiologic images.

Generally, special techniques and equipment are required for this purpose.

But the photographic masking method is practical because special equipment is not required.

In this study, the masking method was investigated enhance radiologic images. The form of filters were examined and X-Ray pictures were processed by high-pass or band-pass filters.

By those processed, details of bone structure, vesșels and so on were clearer and sharper then original images.

\section{1. 結 言}

X線写真に種々の周波数フィルタリングをほどとし， フィルム内にある情報を, より多く取り出して診率に役 立てようとする試みは，各種行なわれてきている，その 中でも写真技術における，マスキング法を用いて行なう 周波数フィルタリングは, フランホーファー回析や, 電 子計算機による画像処理に比べ，装置が簡単である事や， 操作が楽な事, 及びライフサイズのまま処理できる等の 利点があり，最む実用性が高い之考えられるが，X線写 真の密着焼を用いてマスキングした場合のフィルターの 形はほとんど研究されていない. そこで，乙の方法にお ける作製可能なフィルターの形を榆討すると共に，X線 写真を本法で処理し, 処理前の像よりも, 観察しやすい
像を得ることができたので報告する。

\section{2. マスキング法}

一般にコントラストの低い原画よりポジティブ像及び ネガティブ像を作製すると，

$$
\begin{aligned}
& g_{p}(x, y)=1+\gamma_{p} \bar{g}(x, y) * h_{p}(x, y) \\
& g_{N}(x, y)=1-\gamma_{N} \bar{g}(x, y) * h_{N}(x, y) \\
& r_{p}, r_{N} \quad \text { 各フィルムの } \gamma \\
& h_{p}, h_{N} \text { 像作製の際の点像分布関数 }
\end{aligned}
$$

合成像は

$$
\begin{aligned}
i(x, y) & =g_{p}(x, y) g_{N}(x, y) \\
& \fallingdotseq 1+\gamma_{p} \bar{g}(x, y) * h_{p}(x, y)-\gamma_{N} \bar{g}(x, y) * h_{N}(x, y) \\
\text { そのフーリエ変換は } & \\
I(\mu, \nu) & =\delta(\mu, \nu)+\bar{G}(\mu, \nu)\left[\gamma_{p} H_{p}(\mu, \nu)-\gamma_{N} H_{N}(\mu, \nu)\right]
\end{aligned}
$$




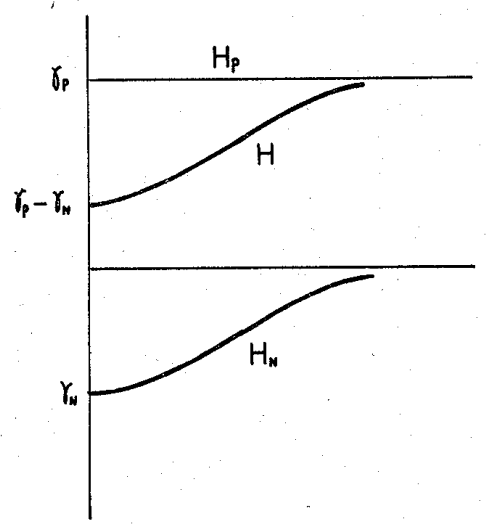

Fig. 1. マスキングによるフィルター

この処理の OTF は

$T(\mu, \nu)=\left\{\begin{array}{l}1 \quad \mu=\nu=0 \\ \gamma_{p} H_{p}(\mu, \nu)-\gamma_{p} H_{N}(\mu, \nu) \quad \mu \neq 0 \quad \nu \neq 0\end{array}\right.$,

従って $\gamma_{p}, \gamma_{N}, H_{p}, H_{N}$ を適当な形にする事によって, 各種のフィルター形が得られる。 $g_{N}(\mathrm{x}, \mathrm{y})$ をマスクと 呼ぶ (Fig. 1)

\section{3. 実験及び結果}

\section{1 フィルム}

適当なガンマのフィルムを求める為, サブトラクショ ンフィルムをミクロファインにて手現像したもの, 自現 処理したむの，及び，コダック RP/M フィルムを自現 処理したものを用いた（Fig.2）。

\section{2 焼付}

燒付は散乱光による密着焼で行ない，ボケが必要な場 合は,フィルム間に透明フィルムによるスペーサーを洀 入した (Fig. 3).

3.3 OTF

密着燒付及び各種ボケを与えた時の OTF を. Fig. 4 往す。

\section{4 高域フィルター}

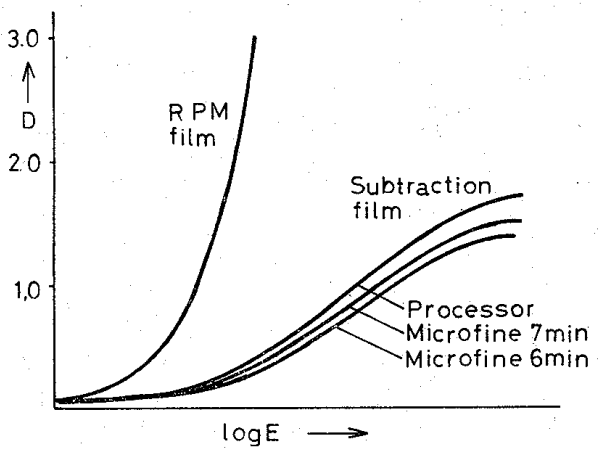

Fig. 2. 特 性 曲 線
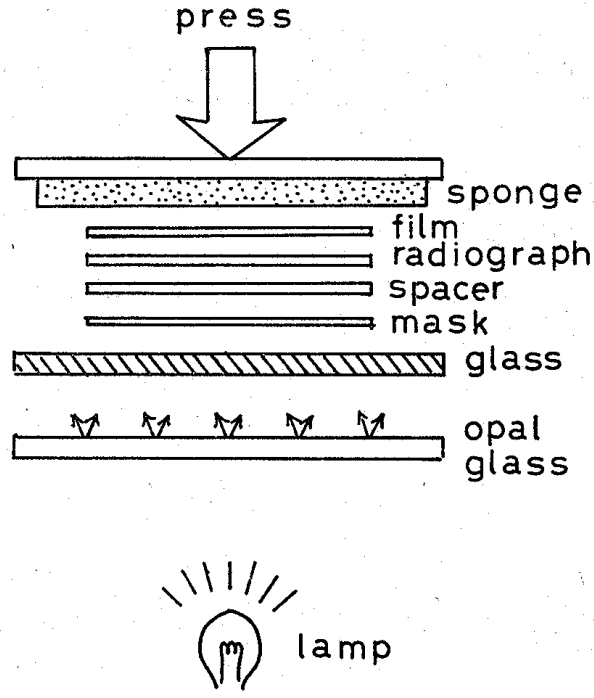

Fig. 3. 露 光 方 法

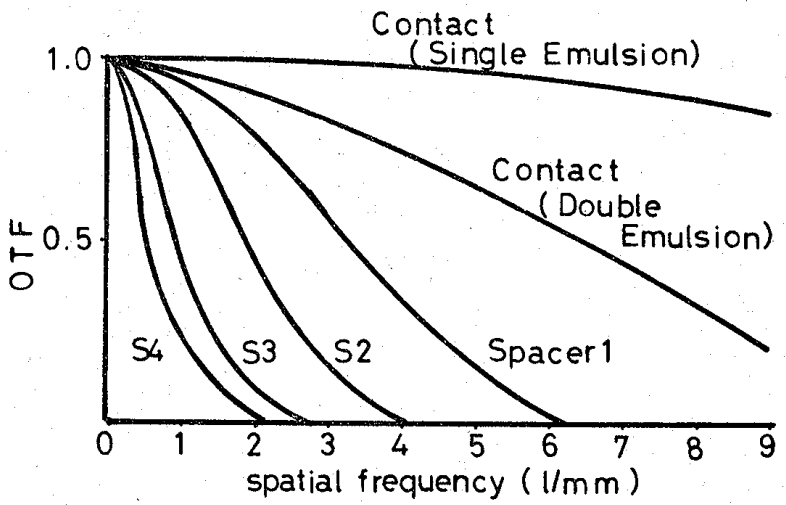

Fig. 4. OTF

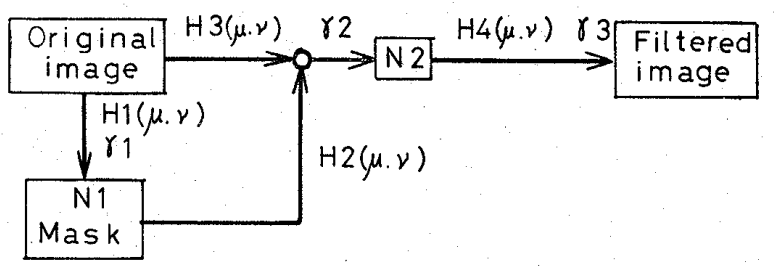

Fig. 5. 高域フィルター バンドパスフィルター

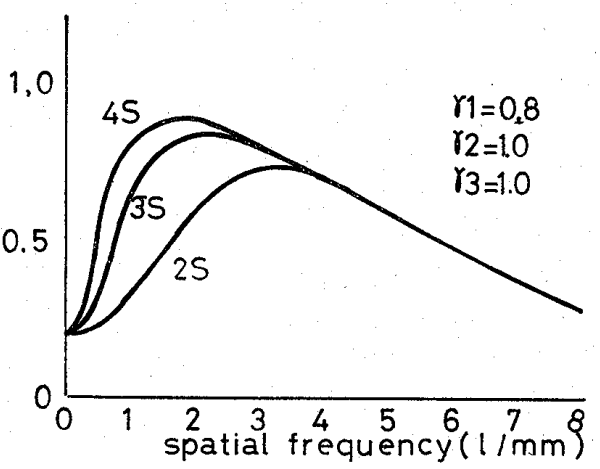

Fig. 6. 高域フィルター 
写真技術を用いた $\mathbf{X}$ 線写真のフィルタリング（畑川）

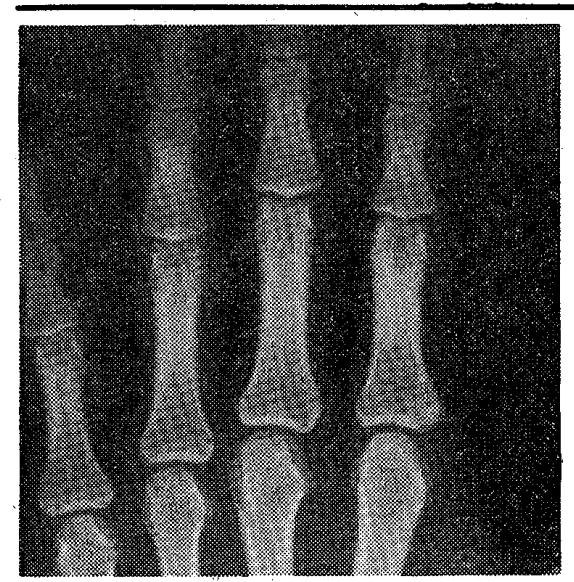

Fig. 7. a-1 原画

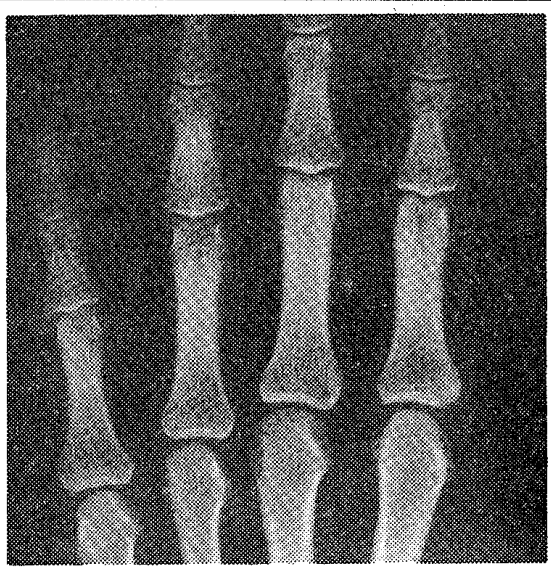

Fig. 7. a-2 高域フィルター $2 \mathrm{~S}$

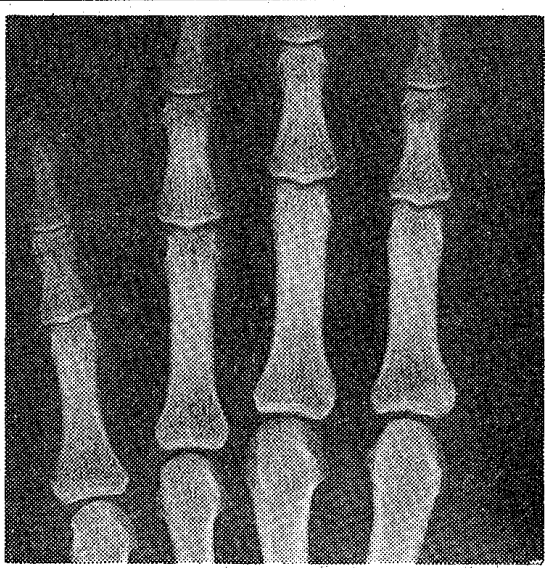

Fig. 7. a-3 高城フィルター $4 \mathrm{~S}$

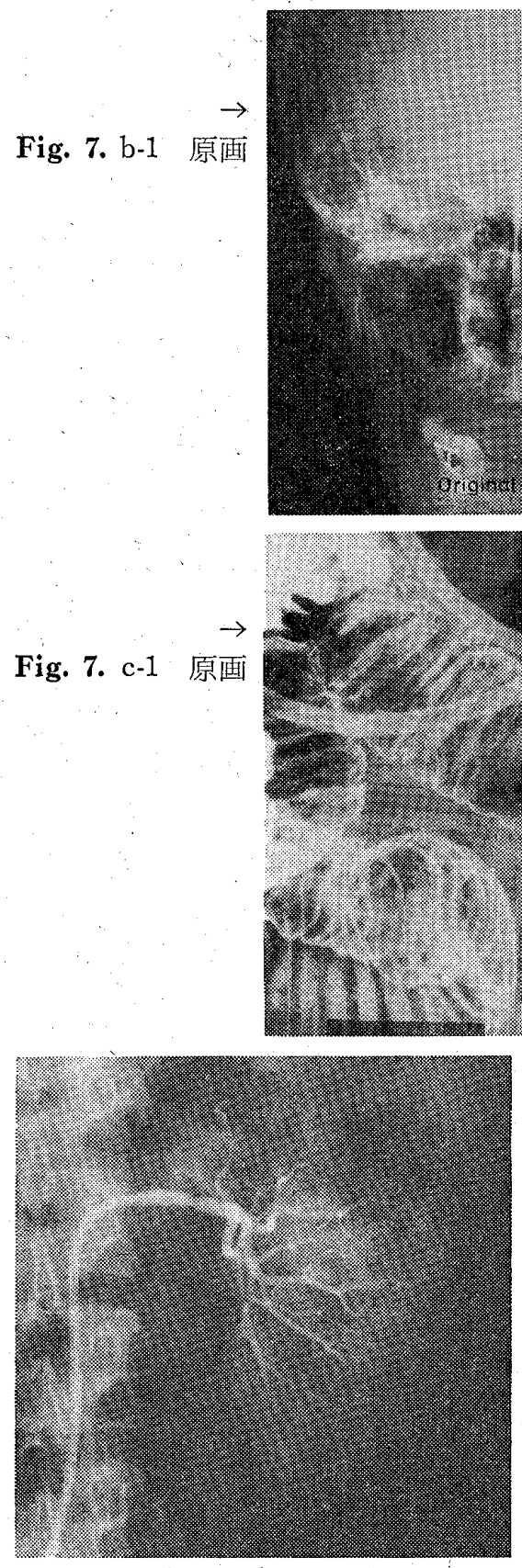

Fig. 7. d-1 原画

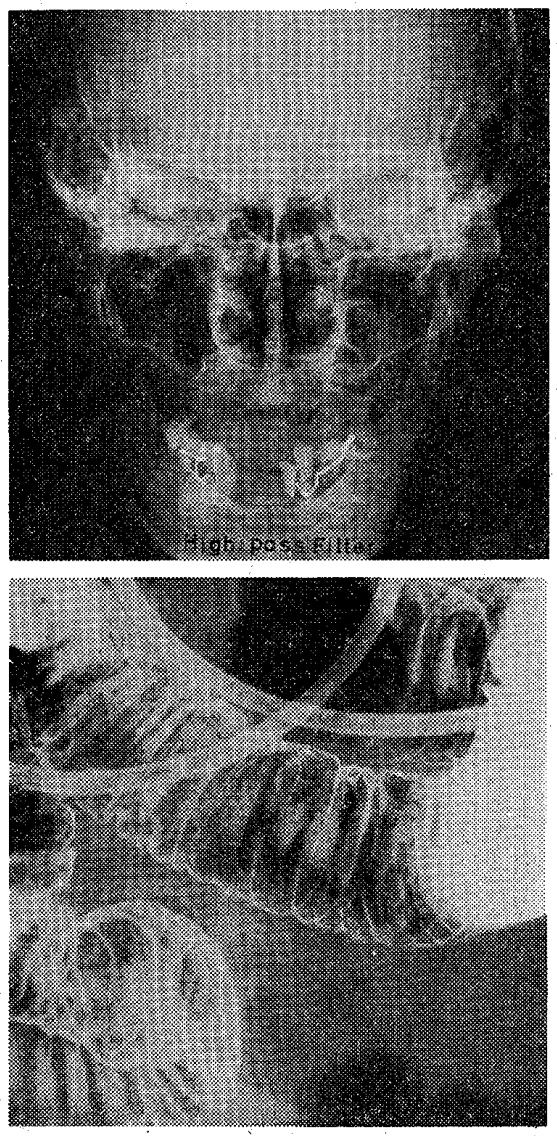

Fig. 7. b-2

高域フィルター $2 \mathrm{~S}$

Fig. 7. c-2

高域フィルター $3 \mathrm{~S}$

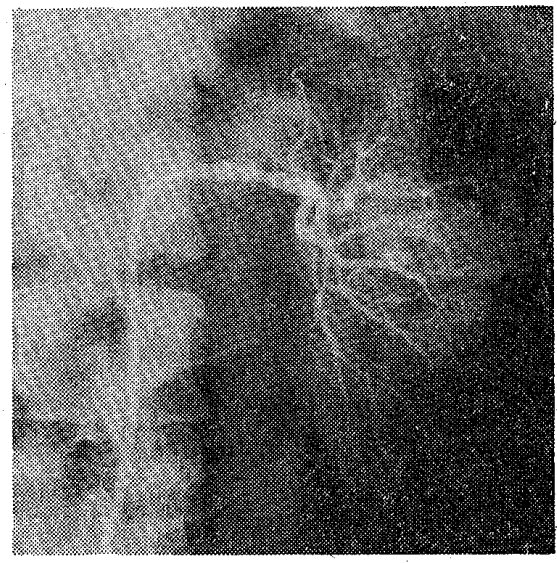

Fig. 7. d-2 高域フィルター3S $-(110)-$

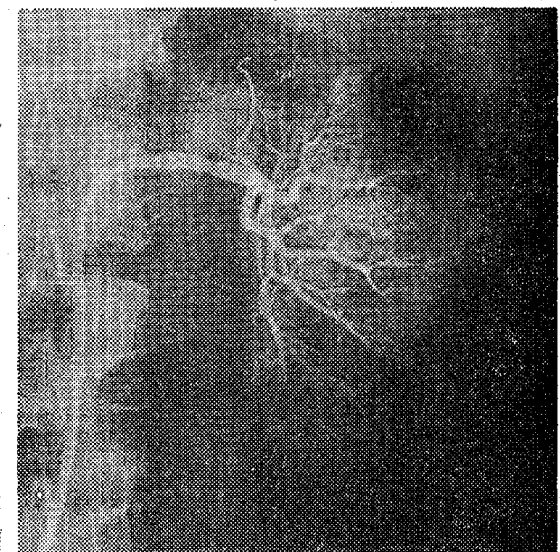

Fig. 7. d-3 バンドパスフィルター 
Fig. 5 に示すブロック図に従って焼付処理を行なう た。

この処理の OTF, $\mathrm{T}(\mu, \nu)$ は

$T(\mu, \nu)=\left\{\gamma_{1} H_{1}(\mu, \nu) H_{2}(\mu, \nu)+H_{3}(\mu, \nu)\right\} \gamma_{2} H_{4}(\mu, \nu) \gamma_{3}$. となり，1>r, $\mathrm{H}_{3}$ を平坦な結像系， $\mathrm{H}_{2}$ を低域フィル ター，すなわちボケを与えれば，乙の処理は高域フィル ターとなる.との OTF を Fig. 6 亿示す.グラフ中2s， $3 \mathrm{~s}$, 等はマスクにボケを与える為使用したスペーサーの 枚数を，生フィルムの乳剤面より芫た枚数に換算したも のである・

この方法に徉ってX線写真を処理したものをFig. 7 に 示す.

a は手指の写真で a-1 は原画，a-2 はスペーサー 2 枚, a-3 はスペーサー4 枚で処理したものである。骨稜は強 調されシャープに観察される。

b は頭部で，b-1 は原画，b-2、はスペーサー 2 枚で処 理したすのである.

c 佉小腸の 2 重造影で, 蛋白漏出性胃腸症がある, c-1 が原画，c-2 はスペーサー2 枚で処理した。

d は腎血管造影で, d-1 が原画, d-2 がスペーサー3 枚での処理像である.

いずれす処理像は原画に比べ，血管や，微細部分が強 調され観察しやすくなっているが，高域広がっている と思われる各種ノイズも強調されノイズの目立った写真 となっている。

\section{5 バンドパスフィルター (1)}

このフィルターは高域フィルターの高域を低下させる ことにより作製できる。すなわち $\mathrm{H}_{2}(\mu, \nu)$ を低域フ ィルター $\mathrm{H}_{2}(\mu, \nu)$ をわずかに低域フィルターとし， $\gamma_{1}<1$ とすればバンドパスフィルターとなる. OTFを Fig. 8 亿示す.との形のフィルターは前記のノイズを消 去するのに効果があると思われる。

本フィルタリングによる処理像を Fig. 7 d-3 に示す.
$H 5(\mu . \nu)$

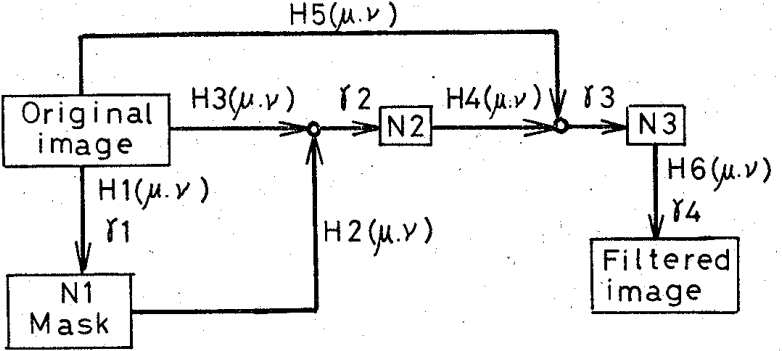

Fig. 9. バンドパスフィルター2

高域が低下している為，ボケたように感じる部分あある が血管は原画よりシャープに観察されている。ノイズは 3.10高域フィルターに比べ減少しているが，完全には とれていない。

\section{6 バンドパスフィルター(2)}

ある範囲の周波数のみをカットする目的のフィルター で, ブロック図を Fig.9 亿示す。この処理の OTF は $T(\mu, \nu)=\left[\left\{\gamma_{1} H_{1}(\mu, \nu) H_{2}(\mu, \nu)+H_{3}(\mu, \nu)\right\} \gamma_{2} H_{4}(\mu, \nu)\right.$

$$
\left.+H_{5}(\mu, \nu)\right] \gamma_{3} H_{6}(\mu, \nu)
$$

$\mathrm{H}_{2}(\mu, \nu)$ 低域フィルター

$H_{3}(\mu, \nu)$ わずかに低域フィルター

$H_{1}(\mu, \nu) H_{4}(\mu, \nu) H_{5}(\mu, \nu) H_{6}(\mu, \nu)$ 平坦

$1<r_{1}$ とする

OTFを Fig. 10 亿示す.

このように焼付ける操作が多くなると，フィルムベー ス自体によるボケが増加し，フィルターの形がなまった あのとなり，ある周波数において OTF むつかしい：利用法としては，リス目の除去等であろう が実際処理した結果ではグラフから予想されるように少 しグリッドのコントラストが落ちたのみである.

\section{7 フィルムの非直線性による影響}

原画のダイナミックレンジが燒付フィルムの直線域よ り大きい場合，濃度域全面にわたって均一な処理ができ ない.

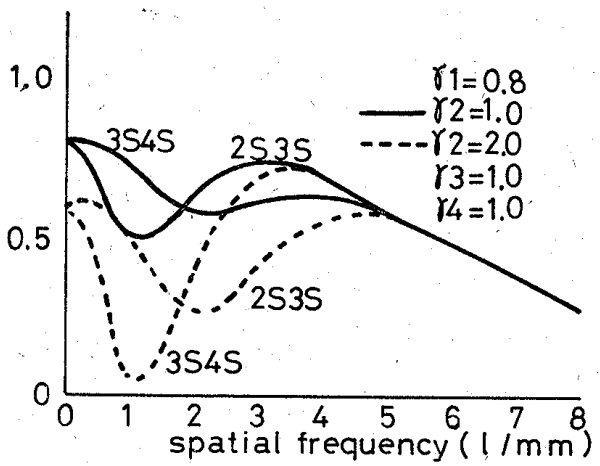

Fig. 10. バンドパスフィルター 2

Fig. 8. バンドパスフィルター1 

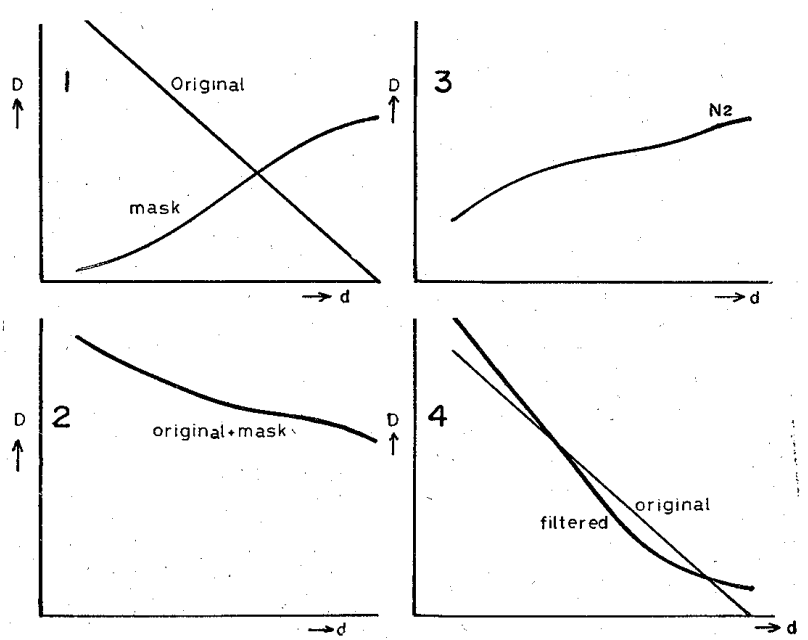

Fig. 11. 濃 度 変 化

Fig. 4 のブロック図に执いて, $\mathrm{H}_{2}(\mu, \nu)$ にボケを与え ない場合の処理過程の濃度変化を Fig. 11 亿示す. クサビ状の濃度をすつ原画を処理したものであるが， 処理像はかなり原画に近い濃度をすったものが再現され ている。

\section{4. 考察及び結論}

X線写真の密着焼を用いたマスキング法によって処理 する場合のフィルターの形を知るととができた。

X線フィルムは雨面乳剤の為, 焼付ける度にベースの 厚さによって高域が低下する．従って完全な高域つィル ターは作製不可能である，しかし撮影系の MTFを考慮 した時，実質的には高域フィルターと考えられる。

又, バンドパスフィルターも,フィルターの形がなま ったあのとなるが作製可能である．しかし，との場合も 両面乳剂の為高域でのバンドパスフィルターは不可能で ある。

実際処理上での注意すべき点は，原画とマスクを重ね合 せる時，像がズレると微分像を呈するとと，マスクの が，部分的にも1より高いとその部分が反転像となる事 等である。
てれらの処理の結果, 微細部分は高域フィルターによ って空間周波数 $2 \sim 3$ 本 $/ \mathrm{mm}$ 附近が強調され，原画よ り見やすくなっている.とのととは視覚系のレスポンス とも一致する! 又，バンドパスフィルター1によって高 域を低下させるととによりノイズの除去を試みたが，む まり効果はなかった。

この原因は，フィルターの形がなまっているととと， ノイズの周波数, 種類（加算的, 乗算的）によるものと 思われる。

臨床的には，一般骨部，血管造影等微細部分の診断に は，高域フィルターを用いる事により観察しやすくなり 有用であろう.

しかし診断には原画と比較して観察するととは必要で ある。

終りに御指導，ご協力下さいました大阪市大工学部北 浜研の方々，ならびに当院放射線科諸兄に深く感謝いた します。

（本論文の要旨は昭和50年4月5日第 31 回日本放射線技 術学会総会及び昭和50年9月5日日本放射線医学会物理部 会において発表した。）

\section{文献}

1）过内順平，村田和美：光学情報処理，朝食書店， 1974.

2) 滝保夫, 青木昌治, 樋渡消二: 画像工学, コロナ社, 1973.

3）小林正敏ほか：脳血管造影写真のサブトラクション， 日放技術学会誌，第29巻， 3 号 260 .

4）汇森康文：視覚之画像，画像技術，Vol.4，No.6, 1973

5）安田嘉純：画贔の主観的評佂，画像技術，Vol. 4, No. 6, 1973.

6) Rossman, K. et al: Optical Spatial Filtering of Radiographic Images with Binary Filters, ${ }_{-}^{\text {T }}$ Radiology 111, 433-438, (1974). 